\title{
Desain dan Implementasi Variasi Dimensi Slot Pada Mikrostrip Double F Menggunakan Metode Finite Difference Time Domain (FDTD)
}

\section{The Design and Implementation of Slot Dimension Variation on Double F Microstrip using FDTD Method}

\author{
Nurista Wahyu Kirana ${ }^{a, *}$, Sholeh Hadi $P^{b}$, Erni $Y^{b}$ \\ ${ }^{a}$ Teknik Elektro Universitas Brawijaya \\ Jalan M.T. Haryono 167 Malang 6514, Indonesia \\ ${ }^{b}$ Laboratorium Teknik Elektro Universitas Brawijaya \\ Jalan M.T. Haryono 167 Malang 6514, Indonesia
}

\begin{abstract}
Abstrak
Pada penelitian ini dirancang antena mikrostrip dengan slot double $F$, di mana antena ini dapat digunakan untuk perangkat wireless yang bekerja pada frekuensi multiband. Antena mikrostrip double $F$ dirancang dengan simulasi, dipabrikasi dan diukur secara riil. Finite Difference Time Domain (FDTD) digunakan untuk menganalisis karakteristik distribusi arus yang tersebar pada mikrostrip. Nilai parameter terbaik dari hasil simulasi untuk return loss adalah $-31,09 \mathrm{~dB}$ pada frekuensi $2,4 \mathrm{GHz}$ dan VSWR sebesar 1,057 sedangkan hasil pengukurannya sebesar -32,82 dB pada frekuensi 2,4 GHz dan VSWR sebesar 1,045 . Penggunaan slot pada patch antena dan pencatuan proximity yang digunakan meningkatkan bandwidth antena sebesar $48,7 \%$ dan gain yang dihasilkan sebesar 5,97 dBi.
\end{abstract}

Kata kunci: bandwidth, FDTD, return loss, VSWR, gain.

Abstract

In this paper, the characteristics of microstrip antenna using a double F slot are studied. It can be used for a wireless device that works on multiband frequency. Double F slot and proximity feed are used in order to obtain larger bandwidth and multiple frequency. Finite Difference Time Domain (FDTD) is used to analyze the characteristics of the current distribution on the patch by changing the variable of slot's length. From the simulation results, return loss of double F slot antenna is -31.09 $d B$ at $2.4 \mathrm{GHz}$ and VSWR is 1.057. Afterwards, the measurement result has $-32.82 \mathrm{~dB}$ at $2.4 \mathrm{GHz}$ and VSWR is 1.045. From the study, the usability of slot size and proximity feed give effect to increase the bandwidth until $48.7 \%$ and $5.97 \mathrm{dBi}$ gain.

Keywords: bandwidth, FDTD, return loss, VSWR, gain.

\section{Pendahuluan}

Teknologi wireless semakin dibutuhkan seiring dengan kebutuhan manusia untuk komunikasi mobile yang terus berkembang. Dalam upaya mendukung proses komunikasi wireless dibutuhkan peranan antena dalam proses transmisinya. Karakteristik antena yang dibutuhkan untuk komunikasi wireless yaitu mempunyai ukuran kecil, ringan, biaya rendah, proses pabrikasi yang mudah, dapat diintegrasikan dengan perangkat microwave dan conformal (dapat menyesuaikan dengan tempat di mana antena tersebut diletakkan) [1]. Antena mikrostrip merupakan salah satu jenis antena dengan karakteristik yang tepat akan kebutuhan tersebut. Namun, jenis antena ini memiliki beberapa kelemahan, di antaranya gain rendah, keterarahan yang kurang baik, efisiensi rendah, rugirugi hambatan pada saluran pencatu, eksitasi gelombang permukaan dan bandwidth rendah [2].

\footnotetext{
* Corresponding Author.

Email: nurista.w.kirana@gmail.com

Received: April 26, 2015; Revised: May 11, 2015

Accepted: May 11,2015

Published: June 30, 2015

(c) 2015 PPET - LIPI
}

doi : 10.14203/jet.v15.6-13
Kelemahan yang dimiliki oleh antena mikrostrip dapat diatasi dengan beberapa cara atau metode, di antaranya adalah dengan menggunakan teknik pencatuan atau dengan menambahkan slot pada patch mikrostrip. Penggunaan slot pada antena mikrostrip telah banyak digunakan untuk meningkatkan kinerja antenna terutama bandwidth dan gain seperti penggunaan e-slot, L-slot [3], U-slot [4], dan single slot [5]. Geometri double $\mathrm{F}$ merupakan pengembangan dari slot double $\mathrm{C}$ [6] dan mikrostrip inverted $\mathrm{F}$ [7]. Medan listrik dan medan magnet yang berubah terhadap waktu akan mendasari gelombang elektromagnet. Dari penelitian tentang antena mikrostrip sebelumnya perlu dikaji lebih dalam tentang analisis distribusi arus pada patch antena. Setelah Yee pada tahun 1966 memperkenalkan metode Finite Difference Time Domain (FDTD) untuk menganalisis medan listrik magnet [8], metode ini sekarang banyak diterapkan untuk permasalahan analisis antena. Persamaan rotasi dari persamaan Maxwell merupakan dasar implementasi metode FDTD [9].

Dalam metode FDTD, propagasi gelombang elektromagnetik disimulasikan dalam koordinat tiga dimensi dan wilayah analisis didiskritkan menjadi unit 
sel segiempat atau sel Yee yang berisi komponen medan listrik (medan E) dan medan magnet (medan H) secara berulang. FDTD banyak diterapkan sebagai metode untuk analisis distribusi arus pada patch antena, karena kemudahan untuk analisis permasalahan yang didasarkan pada persamaan integral yang sangat sulit dipecahkan pada metode yang lainnya [10]. Metode FDTD digunakan sebagai analisis distribusi arus antena pada patch mikrostrip seperti bentuk T-patch [11] dan H-patch. Oleh karena itu penulis akan merancang suatu antena mikrostrip dengan slot berbentuk dobel $\mathrm{F}$ pada patch persegi, serta menganalisis karakteristik antena dengan menggunakan metode FDTD.

\section{METODE FDTD}

Dalam menentukan metode FDTD ditentukan terlebih dahulu wilayah analisis yang membungkus sumber gelombang, benda hambur. Lalu wilayah analisis ini dicacah menjadi banyak sel kecil. Setelah itu ditentukan persamaan turunan Maxwell untuk kondisi free space [12] seperti pada Persamaan 1 dan 2.

$$
\begin{aligned}
& \frac{\partial E}{\partial t}=\frac{1}{\varepsilon_{0}} \nabla \times H \\
& \frac{\partial H}{\partial t}=-\frac{1}{\mu_{0}} \nabla x E
\end{aligned}
$$

di mana :

$$
\begin{array}{ll}
\mathrm{E} & : \text { vektor medan listrik, } \\
\mathrm{H} & : \text { vektor medan magnet, } \\
\frac{\partial E}{\partial t} & \begin{array}{l}
\text { : turunan parsial medan listrik } \\
\text { terhadap waktu, }
\end{array} \\
\frac{\partial H}{\partial t} & \begin{array}{l}
\text { : turunan parsial medan magnet } \\
\text { terhadap waktu, }
\end{array} \\
& \begin{array}{l}
\text { : permeabilitas ruang hampa, } \\
\mu_{0}
\end{array} \\
\varepsilon_{0} & : \text { permitivitas ruang hampa. }
\end{array}
$$

Sebagai dasar persamaan gelombang datar dengan medan listrik pada sumbu $\mathrm{x}$ dan medan magnet pada sumbu y yang merambat pada sumbu z [13]. Gambar 1 menunjukkan ilustrasi FDTD 3 dimensi (3D FDTD) di mana wilayah analisis dibagi di dalam beberapa unit sel.

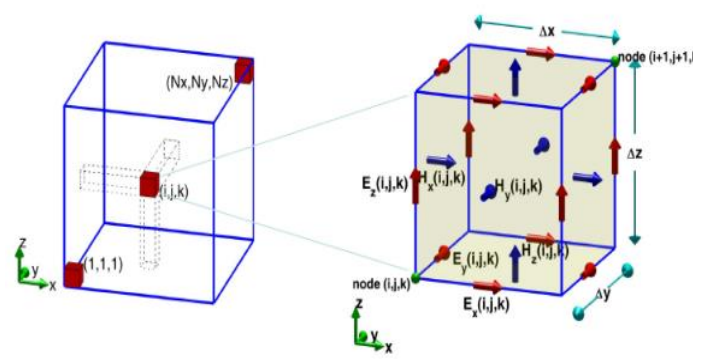

Gambar 1. Unit Sel 3D FDTD yang Merepresentasikan Komponen Medan Listrik dan Medan Magnet di Dalam Sel Yee.

Langkah pertama untuk merancang antena mikrostrip dengan menggunakan FDTD adalah dengan membagi objek menjadi beberapa bagian (mesh grid). Sejumlah parameter harus ditentukan agar program dapat berjalan dengan baik [14]. Ukuran grid harus cukup kecil agar medan yang dicacah dapat mendekati nilai yang akurat. Apabila satu grid tersebut telah dipilih, maka step waktu juga telah secara otomatis ditentukan, sehingga menghindari adanya instabilitas numerik.

Dalam metode FDTD juga diperlukan penetuan titik bagi (grid point) yang paling dekat dengan koordinat $(\mathrm{i}, \mathrm{j}, \mathrm{k})$ yaitu $\mathrm{E}_{\mathrm{z}}(\mathrm{i}, \mathrm{j}, \mathrm{k})$, di mana susunan medan listrik dan magnet terdekat dengan titik bagi ditunjukkan pada Gambar 2.

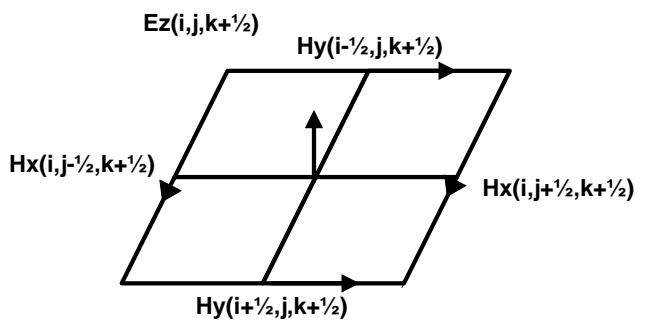

Gambar 2. Penyusunan Medan Listrik dan Magnet di Dekat Titik Bagi $(\mathrm{i}, \mathrm{j}, \mathrm{k}+1 / 2)$.

\section{Desain dan Pabrikasi antena}

Sebelum membuat antena, terlebih dahulu dilakukan perhitungan terhadap dimensi antena berdasarkan rumus yang diperoleh dari studi pustaka. Dari rumus tersebut kemudian diaplikasikan ke dalam simulasi. Simulasi antena menggunakan software CST Microwave studio.

Geometri antena mikrostrip double $F$ yang dirancang seperti ditunjukkan pada Gambar 3. Slot berbentuk double $\mathrm{F}$ diletakkan di atas patch antena. Bahan substrat dielektrik yang digunakan adalah FR4 dengan $\varepsilon_{r}$ sebesar 4,3 dengan ketebalan substrat 1,5 mm.

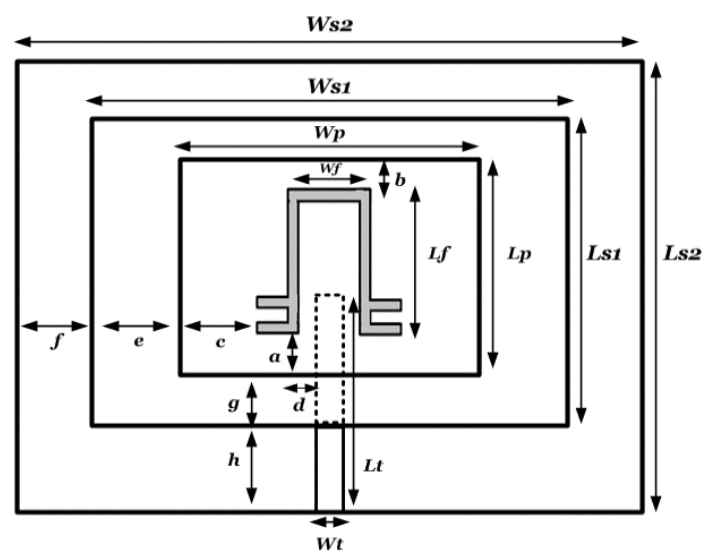

Gambar 3. Geometri Mikrostrip Double F Tampak Depan.

Teknik pencatuan yang digunakan pada penelitian ini adalah pencatuan proximity yaitu teknik pencatuan non-kontak yang bekerja dengan kopling proximity, sehingga saluran pencatu tidak menyentuh resonator. Teknik pencatuan ini juga mempertimbangkan penyesuaian impedansi dari feedline dan saluran transmisi.

Lapisan pertama yaitu lapisan paling atas adalah substrat pertama dengan patch tembaga dan slot double F di atasnya. Kemudian pada lapisan kedua substrat FR4 dengan feedline berbahan tembaga yang dihubungkan dengan konektor RSMA untuk pencatunya. Sedangkan groundplane berbahan tembaga terletak di bagian bawah substrat kedua dengan ukuran sama dengan substrat kedua yaitu $63 \times 73,5 \mathrm{~mm}$ seperti pada Tabel 1 . 
TABEL 1

UKURAN MIKROSTRIP DOUBLE F

\begin{tabular}{|c|c|c|}
\hline $\begin{array}{l}\text { Dimensi } \\
\text { Antena }\end{array}$ & Keterangan & $\begin{array}{c}\text { Ukuran } \\
\text { (mm) }\end{array}$ \\
\hline$a$ & $\begin{array}{l}\text { Jarak slot dan bagian tepi bawah } \\
\text { patch }\end{array}$ & 5 \\
\hline$b$ & Jarak slot dan bagian tepi atas patch & 1,1 \\
\hline$c$ & $\begin{array}{l}\text { Jarak slot dan bagian tepi samping } \\
\text { patch }\end{array}$ & 8 \\
\hline$d$ & Jarak slot dan feedline & 1,5 \\
\hline$e$ & $\begin{array}{l}\text { Jarak antara tepi samping substrat } \\
\text { pertama dan tepi patch }\end{array}$ & 10,4 \\
\hline$f$ & $\begin{array}{l}\text { Jarak antara tepi samping substrat } \\
\text { pertama dan tepi substrat kedua }\end{array}$ & 15 \\
\hline$g$ & $\begin{array}{l}\text { Jarak antara tepi bawah substrat } \\
\text { pertama dan tepi patch }\end{array}$ & 10,5 \\
\hline$h$ & $\begin{array}{l}\text { Jarak antara tepi bawah substrat } \\
\text { pertama dan tepi substrat kedua }\end{array}$ & 7,5 \\
\hline$L_{p}$ & Panjang patch & 27 \\
\hline$W_{p}$ & Lebar patch & 37,5 \\
\hline$L_{f}$ & Panjang slot double $F$ & 21,7 \\
\hline$W_{f}$ & Lebar slot double $F$ & 10,5 \\
\hline$L s_{I}$ & Panjang subsrat pertama & 48 \\
\hline$W s_{1}$ & Lebar subsrat pertama & 58,5 \\
\hline$L s_{2}$ & Panjang subsrat kedua & 63 \\
\hline$W s_{2}$ & Lebar subsrat kedua & 73,5 \\
\hline$L_{t}$ & Panjang transmisi / feedline & 27 \\
\hline$\overline{W_{t}}$ & Lebar transmisi / feedline & 3,5 \\
\hline
\end{tabular}

Selanjutnya, antena yang telah didesain, kemudian disimulasikan dengan menggunakan software CST Microwave Studio dan diuji parameter antenanya. Proses selanjutnya yaitu dilakukan pabrikasi dan pengukuran secara riil terhadap parameter antena. Mikrostrip double $F$ yang telah dipabrikasi ditunjukkan pada Gambar 4.

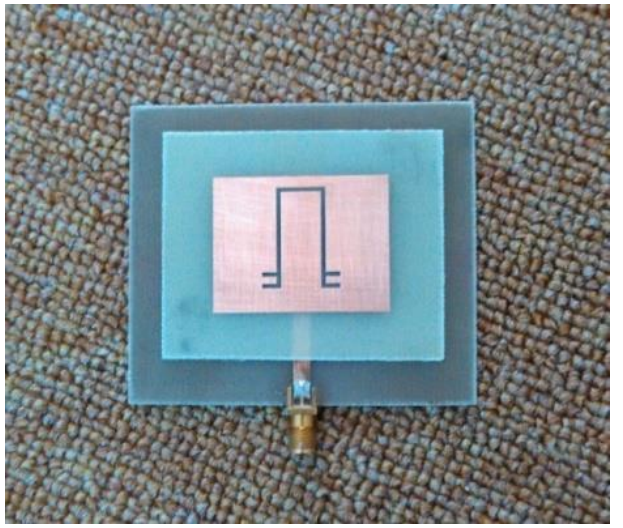

Gambar 4. Antena Mikrostrip Double F yang Telah Dipabrikasi, Pencatu Feedline Dihubungkan Dengan Konektor RSMA Jack Female.

\section{PengujIan Antena}

\section{A. Set-Up Pengukuran}

Setelah dilakukan proses pabrikasi, langkah selanjutnya adalah melakukan pengujian sistem untuk memperoleh data berupa parameter antena. Langkah set up pengukuran parameter antena seperti pada Gambar 5.

Antena mikrostrip dihubungkan dengan Agilent Vector network analyzer N9923A dengan menggunakan kabel pigtail untuk memperoleh nilai return loss, VSWR, dan impedansi. Parameter lain yang diukur adalah gain antena. Dalam penelitian ini, antena referensi yang digunakan adalah antena USB Adapter Wifi TPLink TL-WN722N. Setelah mengukur gain,

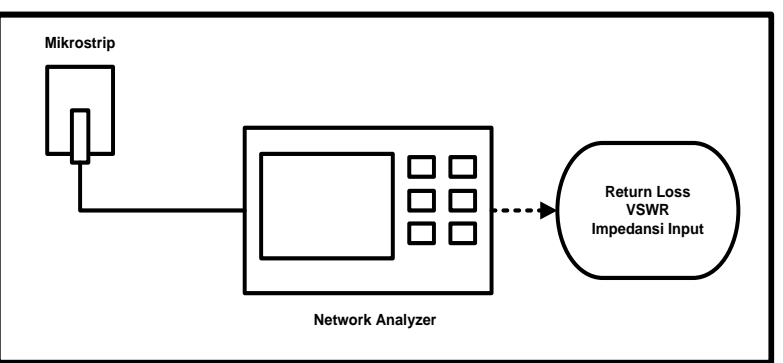

Gambar 5. Set-up Pengukuran Parameter Antena Dengan Network Analyzer.

langkah selanjutnya yaitu mengukur pola radiasi antena. Pengukuran ini dilakukan dengan dua macam, yaitu di bidang medan listrik (bidang E) dan bidang medan magnet (bidang $\mathrm{H}$ ). Pengukuran pola radiasi horizontal dilakukan cara memasang antena standar (access point TP Link) secara vertikal pada suatu tripod dengan asumsi ketinggian antara antena standar dan antena yang akan diukur (antena mikrostrip double $F$ ) memiliki ketinggian yang sama seperti terlihat dalam Gambar 6 .

Antena mikrostrip double $F$ juga diletakkan secara horizontal terhadap pencatunya, atau dengan acuan sudut awal $0^{\circ}$. Kemudian antena mikrostrip double $F$ diputar secara periodik sejauh $10^{\circ}$ searah jarum jam. Tiap kali putaran dicatat hasil level daya yang terukur pada perangkat $R F$ spectrum analyzer. Proses ini dilakukan sampai jarak putaran menempuh $360^{\circ}$. Sedangkan untuk pola radiasi vertikal, sebagai acuan digunakan sudut awal $90^{\circ}$, dengan variabel yang berubah adalah tiap $10^{\circ}$ sampai jarak putaran menempuh $360^{\circ}$.

\section{B. Metode Penelitian}

Selain memperoleh hasil pengujian parameter antena dari hasil simulasi dan pengukuran, maka langkah selanjutnya yaitu analisis dengan menggunakan metode FDTD. Gambar 7 menunjukkan tentang algoritma FDTD.

Analisis gelombang elektromagnetik dilakukan dengan merubah variabel yang berupa dimensi slot yaitu dengan cara mengubah jarak slot dari tepi atas dan samping patch antena. Dari pengujian tersebut dapat dianalisis perubahan yang terjadi pada distribusi arus pada antena dengan metode FDTD.

Perubahan dimensi slot pada patch antena akan diamati perubahan terhadap distribusi arus dan medan listrik. Perubahan jarak slot pada patch antena akan

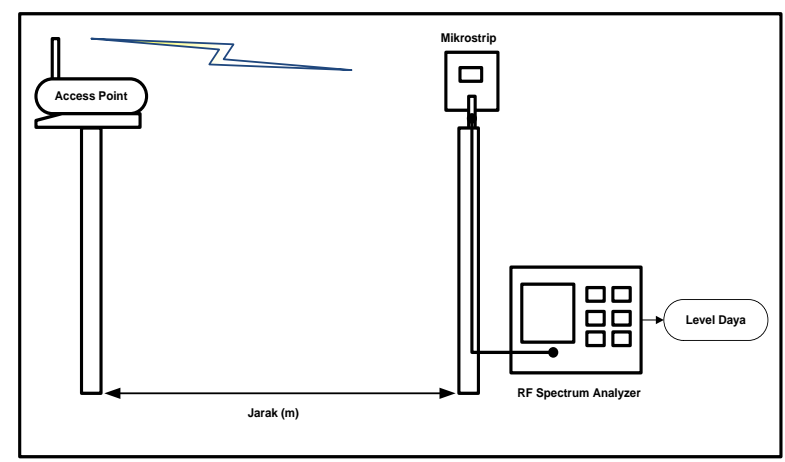

Gambar 6. Set-up Pengukuran Pola Radiasi Antena Dengan Menggunakan Spectrum Analyzer. 


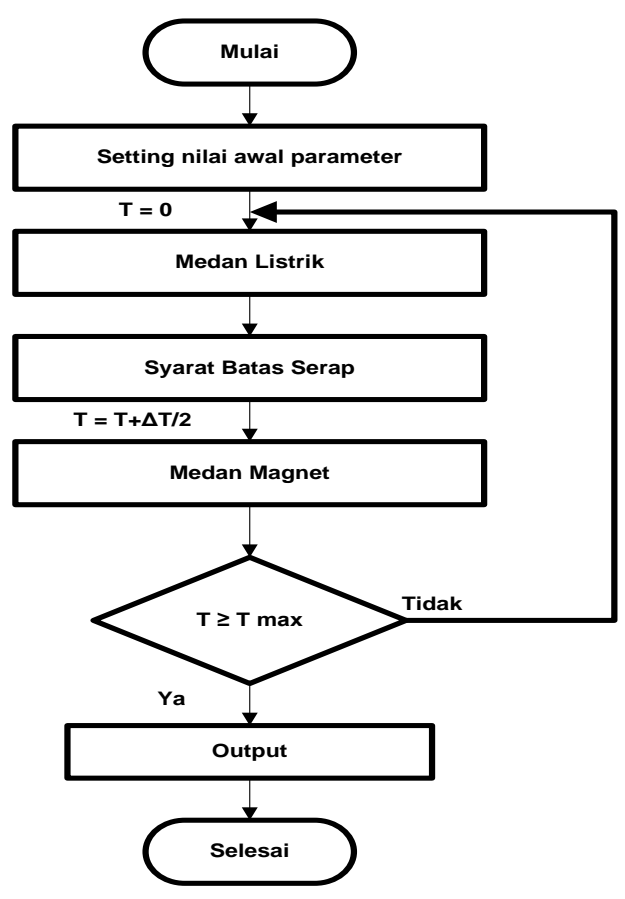

Gambar 7. Algoritma FDTD.

diamati perubahan terhadap distribusi arus dan medan listrik. Perubahan jarak slot terhadap tepi bawah patch (variabel 'a') berpengaruh pada perilaku medan listrik diamati pada patch antena. Kemudian dengan cara yang sama, diubah jarak 'c' yaitu jarak slot dengan tepi samping patch yang berpengaruh juga pada lebar slot. Dari perubahan variabel tersebut, kemudian diamati distribusi arus yang menyebar pada patch antena mikrostrip dengan menggunakan FDTD. Diagram alur metode penelitian dapat dilihat pada Gambar 8.

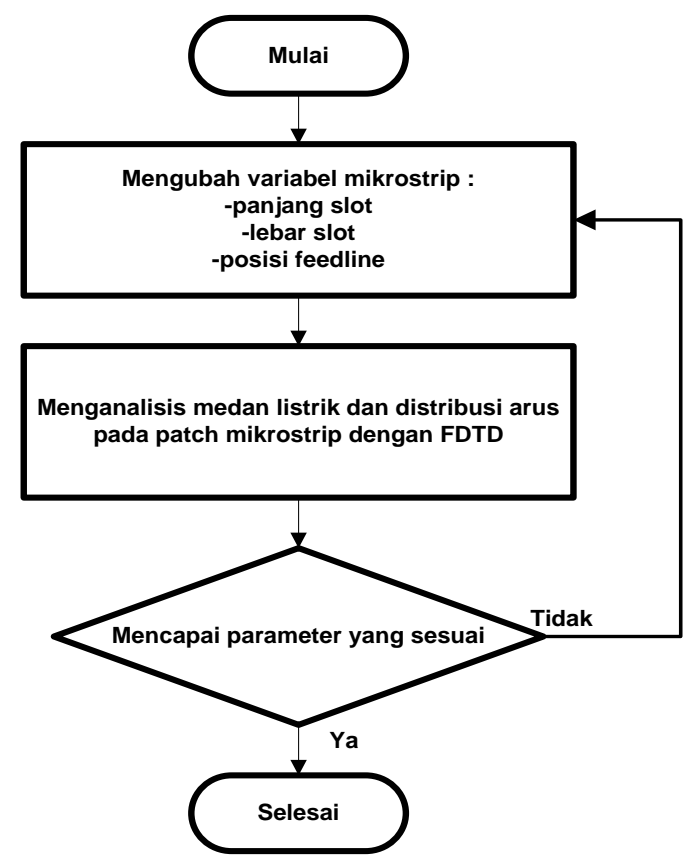

Gambar 8. Flowchart Metode Penelitian.

\section{Hasil Dan ANALISIS}

Dari pengujian antena berupa simulasi dan pengukuran antena yang telah dipabrikasi, didapatkan hasil berupa parameter antena sebagai berikut:

\section{A. Return loss}

Berdasarkan hasil simulasi, tampilan return loss dapat dilihat pada Gambar 9. Berdasarkan hasil simulasi, nilai return loss yang diperoleh pada frekuensi 2,4 GHz adalah -31,09 dB. Frekuensi kerja dari antena mikrostrip double $F$ dapat diketahui dengan cara memasang measured lines pada nilai $-10 \mathrm{~dB}$, dikarenakan batas return loss yang baik adalah di bawah $-10 \mathrm{~dB}$.

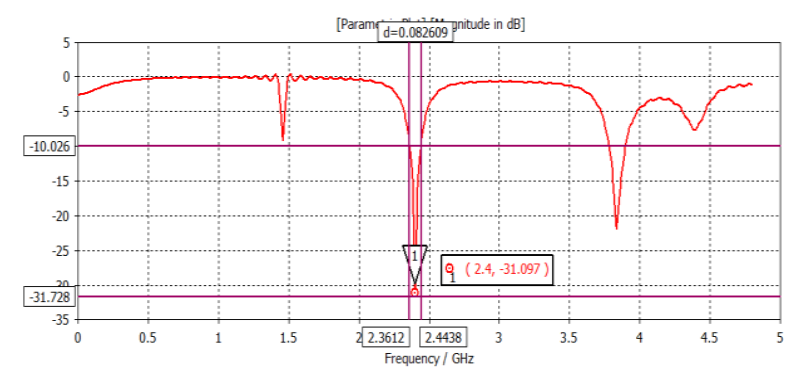

Gambar 9. Hasil Simulasi Return Loss Dengan CST Microwave Studio.

Frekuensi kerja yang diketahui dari hasil simulasi yaitu dari 2,361 GHz sampai dengan 2,443 GHz. Karena antena yang dibuat adalah antena untuk WLAN maka frekuensi kerja mencakup untuk aplikasi WLAN dengan lebar frekuensi sebesar 0,082 GHz. Selain dapat bekerja pada frekuensi WLAN, mikrostrip double $F$ yang telah disimulasikan ini dapat bekerja pada frekuensi 3,832 $\mathrm{GHz}$ dengan rentang frekuensi kerja 3,779 $\mathrm{GHz}$ sampai dengan 3,901 GHz, memiliki bandwidth sebesar 0,122 GHz. Selain hasil simulasi, return loss juga diperoleh dari pengukuran antena yang telah dipabrikasi dengan menggunakan network analyzer seperti terlihat dalam Gambar 10.

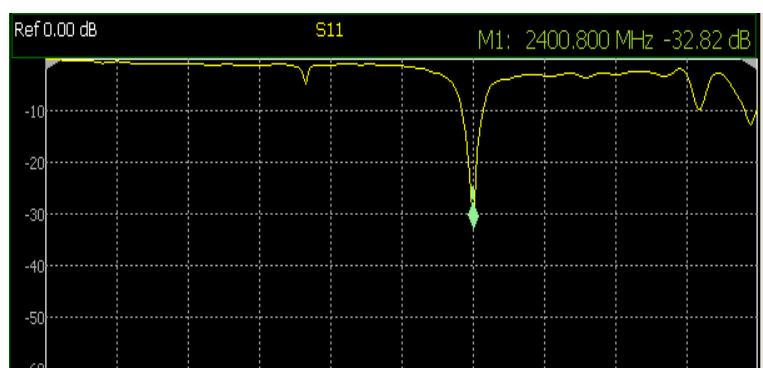

Gambar 10. Hasil Pengukuran Return Loss Dengan Agilent Vector Network Analyzer N9923A.

Gambar 10 menunjukkan bahwa return loss yang dihasilkan dari antena riil yang telah dipabrikasi pada frekuensi 2,4 GHz nilai return loss sebesar $-32,82 \mathrm{~dB}$. Antena hasil pengukuran memiliki range frekuensi kerja dari 2,36 GHz sampai dengan 2,48 GHz sehingga bandwidth-nya sebesar $0,12 \mathrm{GHz}$. Selain bekerja pada frekuensi 2,4 GHz antena mikrostrip yang dibuat juga bekerja pada frekuensi $3,96 \mathrm{GHz}$ yang memiliki nilai return loss sebesar $-15,50 \mathrm{~dB}$.

\section{B. Bandwidth}

Bandwidth antena adalah range frekuensi antena dengan beberapa karakteristik, sesuai dengan standar yang telah ditentukan. Dari penelitian yang telah dilakukan, bandwidth antena dapat diketahui dari frekuensi kerja antena baik dari hasil simulasi maupun dari hasil pengukuran seperti terlihat pada Tabel 2 . 
TABEL 2

BANDWIDTH ANTENA MIKROSTRIP DOUBLE F

\begin{tabular}{|c|c|c|}
\hline \multirow{2}{*}{ Hasil } & $\begin{array}{c}\text { Frekuensi Resonansi } \\
(\mathbf{G H z})\end{array}$ & $\begin{array}{c}\text { Bandwidth } \\
(\mathbf{G H z})\end{array}$ \\
\hline \multirow{2}{*}{ Simulasi } & $2,36-2,44$ & 0,082 \\
\cline { 2 - 3 } & $3,77-3,90$ & 0,122 \\
\hline Pengukuran & $2,36-2,48$ & 0,12 \\
\hline
\end{tabular}

Terlihat pada Tabel 2 bahwa bandwidth pada hasil simulasi untuk frekuensi 2,4 GHz adalah $0,082 \mathrm{GHz}$ sedangkan hasil pengukuran yaitu $0,12 \mathrm{GHz}$.

\section{VSWR}

Salah satu parameter penting lainnya dalam pengukuran antena adalah voltage standing wave ratio (VSWR). VSWR adalah pengukuran dasar dari impedansi matching antara transmitter dan antena. Hasil simulasi untuk tampilan VSWR adalah seperti Gambar 11.

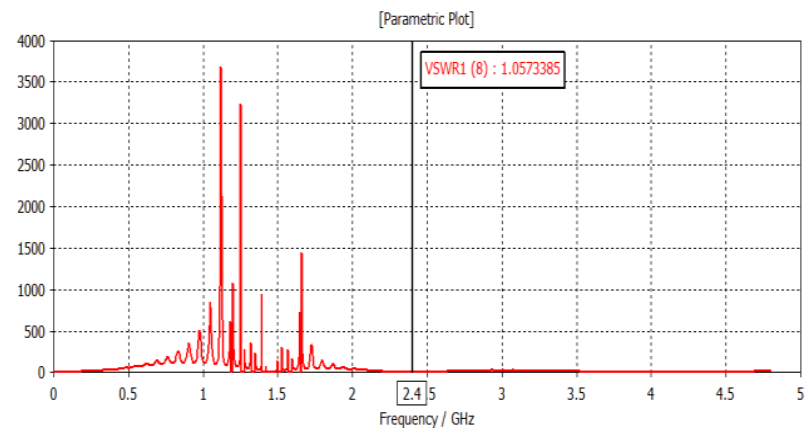

Gambar 11. Hasil Simulasi VSWR Dengan CST Microwave Studio.

VSWR yang diperoleh dari hasil simulasi adalah 1,057. Hal ini membuktikan antena mikrostrip yang telah dibuat memenuhi syarat karakteristik antena yang baik karena nilai VSWR $<2$. Nilai VSWR yang diperoleh cukup baik karena mendekati 1, di mana apabila nilai VSWR $=1$ maka tidak ada gelombang yang terpantul dalam saluran transmisi artinya kondisinya adalah match. Untuk pengujian VSWR yang diujikan dengan network analyzer diperoleh hasil seperti pada Gambar 12.

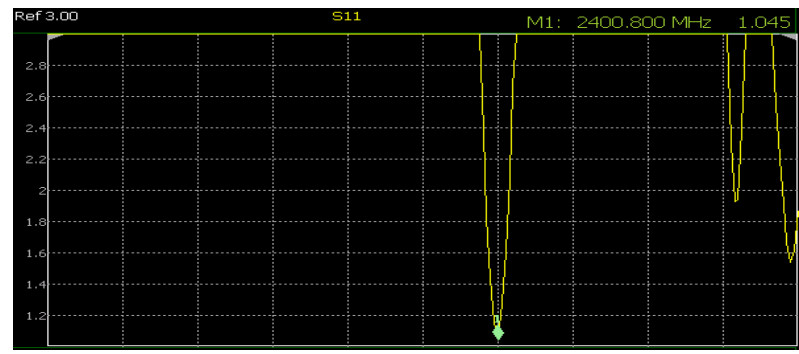

Gambar 12. Hasil Pengukuran VSWR Dengan Agilent Vector Network Analyzer N9923A.

Berdasarkan hasil pengukuran, hasil VSWR yang didapatkan pada frekuensi $2,4 \mathrm{GHz}$ adalah 1,045 . Sedangkan frekuensi $3,96 \mathrm{GHz}$ memiliki VSWR sebesar 1,478. Hasil VSWR antara hasil simulasi dan pengukuran memiliki selisih yang tidak terlalu jauh. VSWR hasil pengukuran juga memiliki nilai $<2$ dan mendekati 1 artinya antena yang dibuat telah memenuhi syarat antena yang baik karena hampir tidak ada gelombang pantul dengan nilai koefisien refleksi yang sangat kecil.

\section{Gain dan Pola Radiasi}

Pada pengukuran gain antena digunakan metode pembandingan (Gain-comparison Method) atau gain transfer mode. Prinsip pengukuran ini adalah dengan menggunakan antena referensi yang sudah diketahui nilai gain-nya. Prosedur ini memerlukan dua kali pengukuran yaitu terhadap antena yang diukur dan terhadap antena referensi. Antena referensi yang digunakan adalah antena USB adapter wifi TLWN722N.

Berdasarkan hasil pengukuran, diperoleh nilai gain sebesar 5,97 dBi sedangkan gain dari hasil simulasi dapat diperoleh dari grafik polar yang dapat dilihat dari magnitude mainlobe yang dihasilkan oleh pola radiasi antena mikrostrip double $F$ seperti pada Gambar 13.

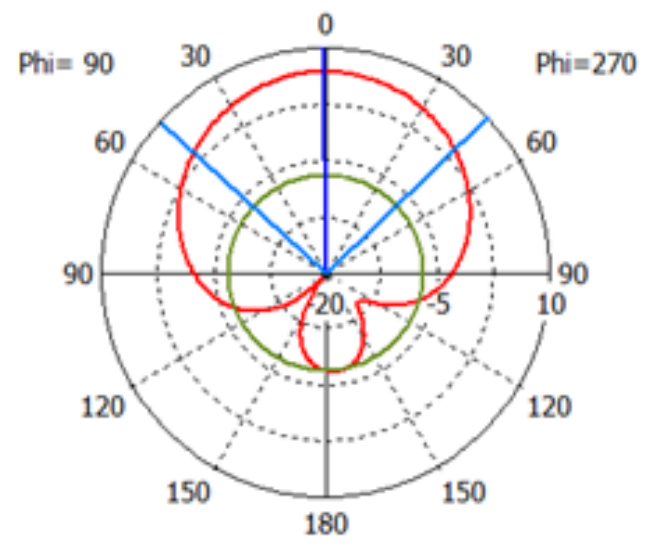

Gambar 13. Pola Radiasi Antena Mikrostrip Double F.

Gambar 13 menunjukkan gain yang diperoleh dari hasil simulasi sebesar $6,85 \mathrm{dBi}$ sedangkan nilai Half Power Beam Width (HPBW) yang diperoleh adalah 93, $5^{\circ}$. HPBW adalah lebar sudut yang memisahkan dua titik setengah daya pada pancaran utama dari pola radiasi. Titik penurunan setengah daya terletak pada 3 $\mathrm{dB}$. Nilai side lobe level (lobe kecil yang ada di dekat main lobe) pada pola radiasi antena adalah $-13,7 \mathrm{~dB}$.

\section{E. Impedansi Antena}

Parameter antena lainnya yang dapat diukur adalah impedansi antena. Dengan menggunakan vector network analyzer, didapatkan nilai impedansi antena pada frekuensi 2,4 GHz adalah sebesar 47,8-j2,1 ohm yang artinya antena mendekati kondisi yang match/sesuai dengan saluran transmisinya (impedansi saluran transmisi sebesar $50 \mathrm{ohm}$ ).

Selain pengujian parameter antena, dari desain antena yang telah dibuat dianalisis dari segi pengubahan variabel dalam hal ini adalah panjang dan lebar slot dengan mengubah jarak slot dengan tepi patch antena (dimensi panjang dan lebar patch antena tetap). Nilai yang diubah adalah 'a' yaitu jarak antara slot dengan tepi bawah antena yang berpengaruh terhadap dimensi panjang slot antena, serta 'c' yaitu jarak antara slot dengan tepi samping patch antena dengan nilai ' $b$ ' yaitu jarak slot dengan tepi atas antena.

1) Pengaruh jarak ' $a$ ' terhadap return loss dan VSWR

Setelah didapatkan hasil parameter antena dari simulasi maupun pengukuran, langkah selanjutnya 
untuk analisis adalah dengan mengubah nilai variabel antena dalam hal ini adalah jarak 'a' yaitu jarak antara slot dengan tepi bawah antena yang berpengaruh terhadap dimensi panjang slot antena sedangkan nilai 'b' dan 'c' tetap. Nilai b diset sebesar 1,3 mm dan c sebesar $8 \mathrm{~mm}$. Nilai a diubah dari $2 \mathrm{~mm}$ sampai dengan $6 \mathrm{~mm}$ dengan step $0,5 \mathrm{~mm}$ sehingga diperoleh nilai perubahan return loss seperti dalam Gambar 14.

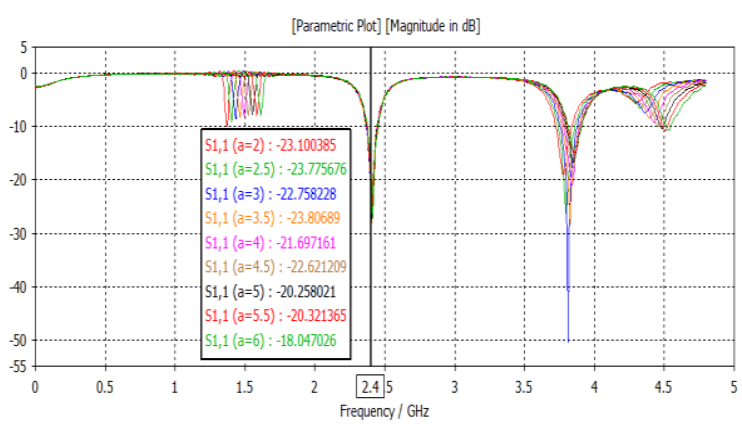

Gambar 14. Pengaruh Jarak a Terhadap Return Loss.

Berdasarkan Gambar 14 di atas dapat dilihat bahwa pengubahan nilai a sebesar $2 \mathrm{~mm}$ sampai dengan $6 \mathrm{~mm}$ dengan step $0,5 \mathrm{~mm}$ sangat berpengaruh terhadap nilai return loss yang dihasilkan. Nilai return loss terbaik terletak pada $\mathrm{a}=3,5 \mathrm{~mm}$ yang mempunyai nilai return loss sebesar $-23,8 \mathrm{~dB}$. Sedangkan pada frekuensi yang lebih tinggi, perubahan jarak slot terhadap patch berpengaruh terhadap pergeseran frekuensi namun tidak terlalu signifikan. Selain return loss, nilai pengubahan variabel a juga berpengaruh pada VSWR antena seperti terlihat dalam Gambar 15.

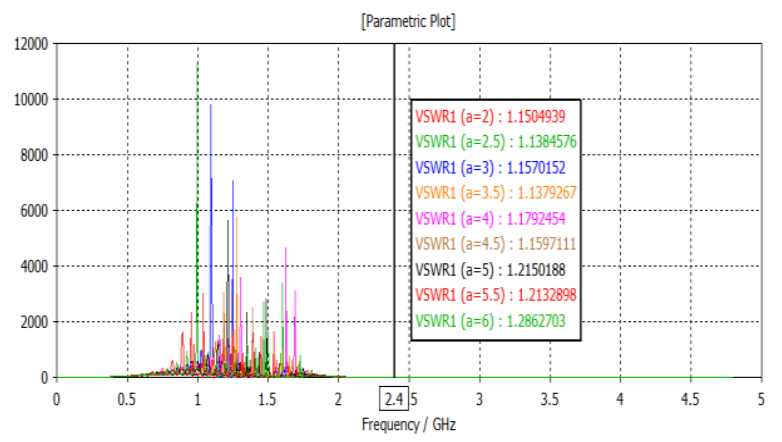

Gambar 15. Pengaruh Jarak a Terhadap VSWR.

Dari hasil VSWR yang diperoleh, menunjukkan bahwa perubahan jarak a terhadap VSWR antena adalah semakin besar nilai a maka VSWR nya juga akan semakin kecil karena nilai return loss nya juga akan semakin besar. Jadi kondisi paling ideal dari antena pada frekuensi $2,4 \mathrm{GHz}$ adalah ketika nilai $\mathrm{a}=3,5 \mathrm{~mm}$ dengan VSWR 1,137.

\section{2) Pengaruh jarak 'c' terhadap return loss dan VSWR}

Selain mengubah nilai a, variabel lain yang diubah adalah dengan mengubah nilai 'c' yaitu jarak antara slot dengan tepi samping patch antena mikrostrip. Nilai c diubah dengan menetapkan nilai a dan b. Berdasarkan hasil pengujian, perubahan variabel c memberi pengaruh pada return loss namun tidak berpengaruh terhadap frekuensi resonansi. Nilai return loss terbaik yaitu $-29,17 \mathrm{~dB}$ pada nilai $\mathrm{c}=9 \mathrm{~mm}$ seperti terlihat dalam Gambar 16, sedangkan pengaruh jarak c terhadap perubahan VSWR antena dapat dilihat dalam Gambar 17.

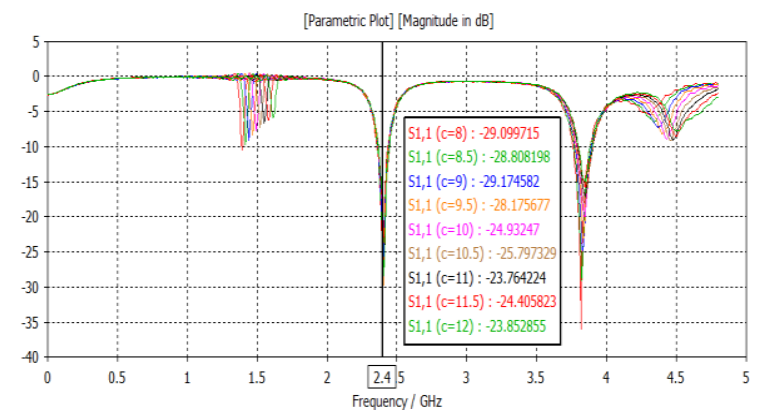

Gambar 16. Pengaruh Jarak c Terhadap Return Loss.

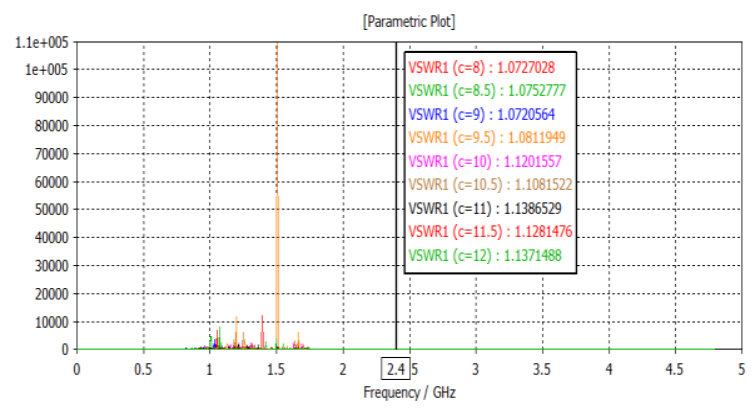

Gambar 17. Pengaruh Jarak c Terhadap VSWR.

Dari hasil VSWR yang diperoleh pada Gambar 17, terlihat bahwa VSWR terbaik adalah pada $\mathrm{c}=9 \mathrm{~mm}$ yaitu sebesar 1,072. Hal tersebut membuktikan bahwa jarak slot terhadap tepi patch antena tidak menggeser frekuensi resonansi secara signifikan namun hanya mengubah nilai return loss dan VSWR pada antena.

\section{3) Pengaruh perubahan jarak a dan c terhadap distribusi arus antena}

Setelah melakukan analisis terhadap parameter antena, langkah selanjutnya adalah menganalisis perilaku distribusi arus yang ada pada antena mikrostrip, dari perubahan nilai a diperoleh distribusi arus yang bervariasi. Dalam hal ini digunakan software Matlab untuk simulasi FDTD yang menggambarkan penyebaran arus pada patch antena. Waktu iterasi maksimal yang digunakan adalah 1 nanosecond (ns) atau 1000 picosecond (ps). Perubahan nilai a terhadap distribusi arus antena dapat dilihat pada Gambar 18.

Berdasarkan hasil yang telah didapatkan pada Gambar 18 dapat dianalisis bahwa perubahan jarak a berpengaruh terhadap distribusi arus antena. Semakin besar nilai a maka distribusi arus pada pusat patch berkurang intensitasnya. Ketika nilai $\mathrm{a}=2 \mathrm{~mm}$, arus pada pusat antena sebesar 0,8 Ampere/meter $(\mathrm{A} / \mathrm{m})$ sedangkan pada saat jarak a diubah menjadi $3 \mathrm{~mm}$, amplitudo arusnya menjadi $0,6 \mathrm{~A} / \mathrm{m}$, dan saat nilai a diubah menjadi $4 \mathrm{~mm}$ maka arus maksimal di pusat antena menjadi $0,5 \mathrm{~A} / \mathrm{m}$ sedangkan saat $\mathrm{a}=5 \mathrm{~mm}$ arusnya menjadi $0,4 \mathrm{~A} / \mathrm{m}$. Namun, dengan waktu yang sama yaitu 299 ps maka semakin besar nilai a maka arus akan semakin menyebar ke tepi patch, hal ini dibuktikan dengan bertambahnya intensitas arus di tepi patch tetapi berkurang pada pusat patch antena. Nilai c diubah dari 8 mm sampai dengan $11 \mathrm{~mm}$ dan dijalankan dengan waktu iterasi 1000 ps. Hasil distribusi arus yang 


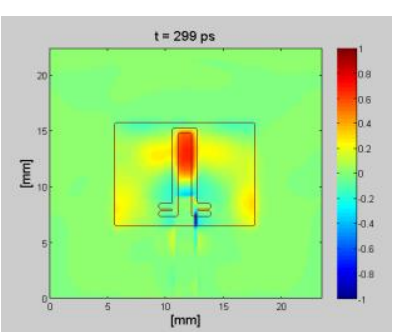

(a)

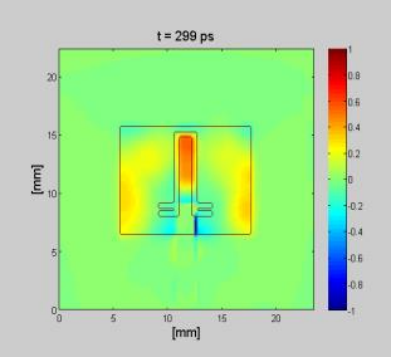

(c)

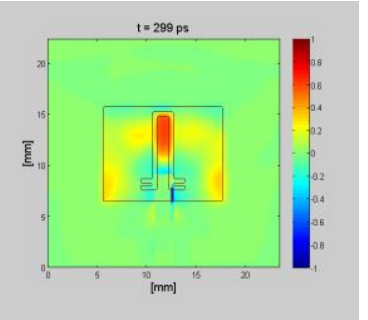

(b)

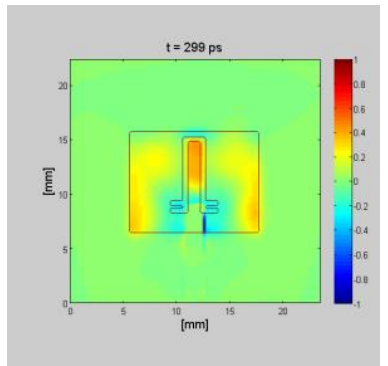

(d)
Gambar 18. Pengaruh Jarak a Terhadap Distribusi Arus Antena pada Timestep 299 ps, (a) Jarak 2 mm, (b) Jarak 3 mm, (c) Jarak 4 mm, (d) Jarak $5 \mathrm{~mm}$.

menyebar pada patch antena dengan perubahan nilai c dapat dilihat dalam Gambar 19.

Berdasarkan hasil yang telah diperoleh, perubahan nilai c mengakibatkan pengaruh terhadap penyebaran arus antena. Semakin besar nilai c maka mengakibatkan dimensi lebar slot menjadi semakin sempit. Hal tersebut berpengaruh pada distribusi arus yang menyebar pada patch antena. Arus pada pusat antena semakin berkurang seiring dengan bertambahnya nilai c. Pada saat $\mathrm{c}=8 \mathrm{~mm}$ dan $\mathrm{c}=9 \mathrm{~mm}$ arus yang ada pada patch sebesar $0,6 \mathrm{~A} / \mathrm{m}$ sedangkan pada $\mathrm{c}=10 \mathrm{~mm}$ dan $\mathrm{c}=11$ $\mathrm{mm}$ arus berkurang menjadi $0,5 \mathrm{~A} / \mathrm{m}$.

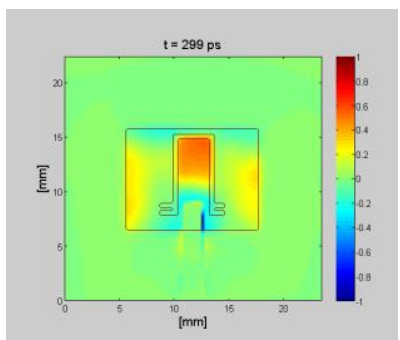

(a)

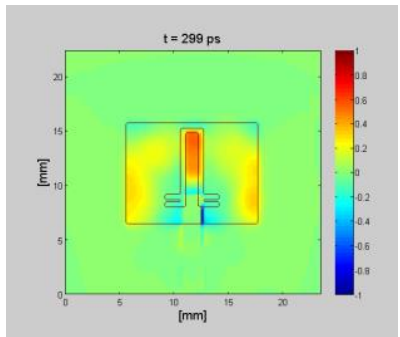

(c)

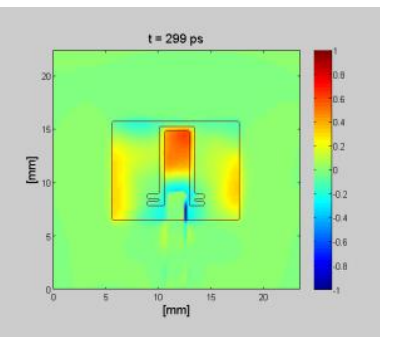

(b)

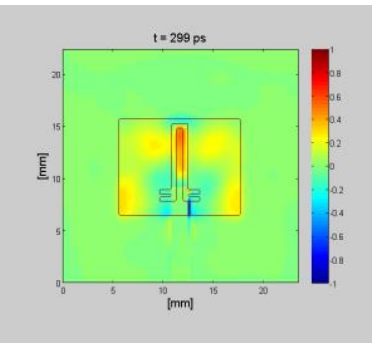

(d)
Gambar 19. Pengaruh Jarak c Terhadap Distribusi Arus Antena pada Timestep 299 ps, (a) Jarak 8 mm, (b) Jarak 9 mm, (c) Jarak 10 $\mathrm{mm}$, (d) Jarak $11 \mathrm{~mm}$.

\section{KESIMPULAN}

Dalam penelitian ini, telah dilakukan perancangan dan pembuatan antena mikrostrip dengan slot double $F$ menggunakan metode Finite Difference Time Domain
(FDTD). Pengujian parameter antena telah dilakukan melalui prosedur pengukuran dan analisisnya berdasarkan perubahan variabel yaitu jarak slot terhadap tepi patch antena yang berpengaruh terhadap dimensi antena. Distribusi arus yang menyebar pada patch antena juga telah dianalisis dengan menggunakan metode FDTD berdasarkan perubahan variabel tersebut. Berdasarkan semua hasil dan pembahasan yang telah dijelaskan pada bagian sebelumnya, maka dapat disimpulkan sebagai berikut:

1. Pada mikrostrip dengan pencatuan proximity tanpa slot, diperoleh nilai return loss sebesar $-18,741 \mathrm{~dB}$ dan bandwidth sebesar $0,077 \mathrm{GHz}$ pada frekuensi 2,4 GHz sedangkan dengan menggunakan slot double $F$ nilai return loss yang diperoleh pada frekuensi 2,4 GHz adalah $-31,09 \mathrm{~dB}$ dan memiliki badwidth $0,082 \mathrm{GHz}$, artinya penggunaan slot double $F$ pada patch mikrostrip dan pencatuan proximity menghasilkan peningkatan bandwidth sebesar 5,1\% serta dapat meningkatkan nilai returnloss dan menurunkan VSWR secara signifikan.

2. Antena hasil pengukuran menghasilkan nilai return loss sebesar -32,82 dB pada frekuensi tengah 2,4 $\mathrm{GHz}$ serta bandwidth antena adalah $0,12 \mathrm{GHz}$ yang artinya meningkat sebesar $48,7 \%$ dari hasil simulasi.

3. VSWR yang diperoleh dari hasil simulasi adalah 1,057 dan pengukuran adalah 1,045. Hal ini membuktikan antena mikrostrip yang telah dibuat memenuhi syarat karakteristik antena yang baik karena nilai $\operatorname{VSWR}<2$. dan mendekati 1 sehingga mendekati kondisi match terhadap saluran transmisinya .

4. Gain yang dihasilkan dari hasil pengujian cukup besar yaitu 5,97 $\mathrm{dBi}$ atau 7,7 kali penguatan dengan pola radiasi omnidirectional, sedangkan pada hasil simulasi direktivitas pada main lobe terbesar memiliki gain sebesar 6,85 dBi.

5. Dengan waktu iterasi yang sama maka semakin besar nilai variabel a (jarak antara slot dengan tepi bawah patch semakin lebar) maka arus akan semakin menyebar ke tepi patch, hal ini dibuktikan dengan bertambahnya intensitas arus di tepi patch tetapi berkurang pada pusat patch antena yaitu dengan $0,8 \mathrm{~A} / \mathrm{m}$ saat jarak $\mathrm{a}=2 \mathrm{~mm}$ dan $0,4 \mathrm{~A} / \mathrm{m}$ pada jarak a $=5 \mathrm{~mm}$.

Berdasarkan hasil yang telah diperoleh, perubahan nilai c mengakibatkan pengaruh terhadap penyebaran arus antena. Semakin besar nilai c maka mengakibatkan dimensi lebar slot menjadi semakin sempit dan arus pada pusat antena semakin berkurang seiring dengan bertambahnya nilai $\mathrm{c}$, hal itu terbukti pada saat $\mathrm{c}=8$ $\mathrm{mm}$ dan $\mathrm{c}=9 \mathrm{~mm}$ arus yang ada pada patch sebesar 0,6 $\mathrm{A} / \mathrm{m}$ sedangkan pada $\mathrm{c}=10 \mathrm{~mm}$ dan $\mathrm{c}=11 \mathrm{~mm}$ arus berkurang menjadi $0,5 \mathrm{~A} / \mathrm{m}$.

\section{UCAPAN TERIMA KASIH}

Ucapan terima kasih kami sampaikan kepada Tim Laboratorium Teknik Elektro Universitas Brawijaya dan Laboratorium Politeknik Kota Malang atas penggunaan peralatan laboratorium. 


\section{Daftar Pustaka}

[1] T. Archevapanich, J. Nakasuwan, N. Songthanapitak, N. Anantrasirichai, and T. Wakabayashi "E-shaped slot antenna for WLAN applications", PIERS Online, vol. 3, no. 7, pp. 11191123,2007

[2] S. Kumar, A. K. Saurabh, and N. S. Beniwal, "Dual band H shaped rectangular microstrip patch antena for WLAN/WiMAX/bluetooth applications", International Journal of Advanced Research in Electrical Electronics and Instrumentation Engineering, vol. 3, iss. 3, pp. 8220-8227, March 2014.

[3] A. Haidery, R. Tawde, and T. Shaikh, "L-slot rectangular microstrip patch antena for WiMAX and WLAN applications", International Journal of Emerging Technology and Advanced Engineering, vol. 3, iss. 10, pp. 471-474, Oct 2013.

[4] M. Ravi and A. Janardhana "Design \& performance analysis of double U-slot microstrip antena for WiMAX application", International Journal of Advanced Research in Electronics and Communication Engineering (IJARECE), vol. 3, iss. 8, pp. 790795, August 2014

[5] R. S. Rathore, S. Baudha, and Shrikant Pandey, "A $2.4 \mathrm{GHz}$ microstrip patch antena with a single slot for WLAN application", International Journal of Advanced Research in Computer Engineering \& Technology, vol. 1, iss. 4, pp. 139-141, June 2012.

[6] B. Thili, "Design of double c-slot microstrip patch antena for WiMax application", in Proceedings of 2010 IEEE Antennas and Propagation Society International Symposium (APSURSI), July 2010, pp. 1-4.
[7] D. K. Karmokar and K. M. Morshed, "Analysis of inverted F and loaded inverted $\mathrm{F}$ antenna for $2,4 \mathrm{GHz}$ ISM band application", Journal of Electrical Engineering The Institution of Engineers Bangladesh, vol. EE 36, no. II, pp. 4-9, December 2009,

[8] D. Sugumar, S. Sydney, D. Athina, and T. J. Selvahephzibah, "Bandwidth enhancement of coaxial feed U slotted microstrip antenna modeled with FDTD algorithm", in Proceedings of IEEE International Conference on Computational Intelligence and Computing Research, 2010.

[9] J. T. S Sumantyo, K. Ito, E. T. Rahardjo, dan K. Saito, Metoda Beda Hingga Kawasan Waktu, Bandung, Indonesia: Penerbit ITB, 2004

[10] A. N. Mahmud, S. S Obayya, A. A. Mitkees, and H. A. Elmikati, "FDTD analysis of a rectangular patch antena on a general uniaxial anisotropic dielectric substrate". in Proceedings of Eighteen National Radio Science Conference, Mar 2001, pp. 131-141 (vol.1).

[11] D. M. Sullivan, Electromagnetic Simulation Using The FDTD Method, New York, USA: John Wiley \& Sons Inc., 2000.

[12] N. Suherman, "Analisis dan pabrikasi mikrostrip horn dilengkap reflektor parabola dengan metode FDTD”, Thesis, Institut Teknologi Sepuluh Nopember, Surabaya, Indonesia, 2008.

[13] A. Hajiaboli, M. Popović, and F. H. Kashani, "Analysis of coaxial-fed electromagnetically coupled patch antenna using FDTD", in Proceedings of IEEE 2005 Antennas and Propagation Society International Symposium, July 2005, pp. 138-141 (vol. 1A).

[14] C. A. Balanis, Antena Theory: Analysis Design, 3rd ed., New Jersey, USA: John Wiley \& Sons, Inc., 2005. 